
${ }^{52}$ Lehninger, A. L., Wadking, C. L., Cooper, C., Devlin, T. M., and

${ }^{33}$ Harrison, K., Nature, 181, 1131 (1958).

st Clark, V. M., Kirby, G. W., and Todd, A., Nature, 181, 1650 (1958). ss Jagendorf, A. T., Brookhaven Symp. in Biology, No. 11, 236 (1958). ${ }^{36}$ San Pietro, A., and Lang, H. M., J. Biol. Chem., 231, 211 (1958).

${ }^{57}$ Hill, R., and Scarisbrick, R., New Phytol., 50, 98 (1951).

${ }^{58}$ Davenport, H. E., Nature, 170, 1112 (1952)

${ }^{59}$ Hill, R., Nature, 174, 501 (1954).

${ }^{60}$ Davenport, H. E., and Hill, R., Proc. Roy. Soc., B, 139, 327 (1952).

${ }^{" 1}$ Elsden, S. R., Kamen, M. D., and Vernon, L. P., J. Amer. Chem. Soc., 75, 6347 (1953).

${ }^{62}$ Vernon, L. P., and Kamen, M. D., J. Biol. Chem., 211, 643 (1954).

${ }^{63}$ Newton, J. W., and Kamen, M. D., Arch. Biochem. Biophys., 58, 246 (1955).

4 Newton, J. W., and Kamen, M. D., Biochim. Biophys. Acta, 21, 71 (1956).

${ }^{65}$ Lundegardh, H., Physiologia Plantarum, 7, 375 (1954).

${ }^{66}$ Duysens, L. N. M., Nature, 173, 692 (1954); Science, 120, 353 (1954); 121, 210 (1955).

${ }^{67}$ Chance, B., and Sager, R., Plant Physiol., 32, 548 (1957).
${ }^{68}$ Chance, B., and Smith, L., Nature, 175, 803 (1955)

"Olson, J., and Chance, B., Biochim. Biophys. Acta, 28, 227 (1958).

${ }^{70}$ Smith, L., and Ramirez, J., Arch. Biochem. Biophys., 79, 233 (1959).

"Nieman. R. H., and Vennesland, B., Science, 125, 353 (1957).

${ }^{2}$ Vishniac, W., Horecker, B. L., and Ochoa, S., Adv. Enzym., 19, 1 (1957).

${ }^{73}$ Ruben, S. J., J. Amer. Chem. Soc., 65, 279 (1943).

${ }^{4}$ Emerson, R. L., Stauffer, J. F., and Umbreit, W. W., Amer. J. Botany, 31, 107 (1944).

${ }^{75}$ Rabinowitch, E. I., "Photosynthesis and Related Processes", 1, 228 (Interscience Publishers, New York, 1945).

${ }^{76}$ Whittingham, C. P., Biol. Rev., 30, 40 (1955).

"Kamen, M. D., "Enzymes: Units of Biological Structure and Function", edit. O. H. Gaebler (Academic Press, New York, 1956).

${ }^{73}$ Arisz, W. H., Proc. Kon. Ned. Akad. Wetensch., C, 50, 1019 (1947).

7 Van Lookeren Campagne, R. N., Acta Botan. Neerl., 6, 543 (1957).

${ }^{80}$ Marrè, E., and Arrigoni, O., Biochim. Biophys. Acta, 30, 453 (1958).

${ }^{81}$ Singer, T. P., and Kearney, E. B., Biochim. Biophys. Acta, 15, 151 (1954).

${ }^{82}$ Bishop, N. I., Proc. U.S. Nat. Acad. Sci., 44, 501 (1958).

\title{
OBITUARIES
}

\section{Sir William Larke, K.B.E.}

Srr William James Larke, who died on April 29, three days after his eighty-fourth birthday, deserves honourable remembrance among scientists for his powerful advocacy of scientific research in the service of industry. Born in 1875, educated at Colfe's School, and trained as an engineer with H. F. Joel and Co., Finsbury, and Siemens Brothers at Woolwich, Larke was engineer and manager of the British Thomson-Houston Company's power and mining department from 1899 until 1912, when he became executive engineer. During the First World War he served with the Ministry of Munitions and was appointed director-general of raw materials in 1919.

In 1922 Larke accepted an invitation to become director of the National Federation of Iron and Steel Manufacturers and it was here that he found his first experience of organizing co-operative research for an entire industry. The result was the establishment of the Iron and Steel Industrial Research Council, of which Sir William was the chairman from 1938 until 1945, and ultimately of the British Iron and Steel Research Association, which now carries on the work.

Sir Charles Goodeve, director of the British Iron and Steel Research Association, writes: "B.I.S.R.A. is now the largest of the research associations and it may not be generally appreciated that its predecessor operated on a small scale with a headquarters staff of about fifteen acting as the technical department of the British Iron and Steel Federation. Under the guidance of Larke and the head of the British Iron and Steel Federation Technical Department, the late Mr. E. C. Evans, a substantial and effective research programme was carried out with a very modest budget, and few can have excelled Larke and Evans in their ability to stretch available funds to the utmost. They had no laboratories of their own and much of the programme was carried out by works personnel or in academic institutions under the general direction of committees serviced by the small central staff. But this staff also did practical work themselves, and the goodwill built up by Larke in steel companies and in university laboratories meant that facilities were readily provided. Between 1924 and 1939 studies of the performance of blast furnaces, open hearth furnaces and rolling mills were carried out and several of the fundamental principles governing efficiency were determined. Many of the methods used were basically similar to those which are now known as operational research".

Sir William was sixty when, in 1935, the international symposium on welding organized by the Iron and Steel Institute convinced him of the importance of the new processes for the joining of metals and of the need for an effective programme of fundamental research in this field. $\mathrm{He}$ was then a member of the advisory council to the Committee of the Privy Council for Scientific and Industrial Research, and with characteristic energy set himself to reorganize the Institution of Welding Engineers and to secure for it the support of such eminent engineers as the late Sir Alexander Gibb, and from the Department of Scientific and Industrial Research and industry the financial backing necessary for a co-operative research organization in welding. From the Institute of Welding's Welding Research Council, of which Larke was chairman from its formation in 1936, came research results of great value in the wareffort of 1939-46, and out of it the present British Welding Research Association was formed in 1946. A leader of scientific research rather than a scientist, Larke inspired both affection and respect in those who worked with him, and the impress of his critical and constructive mind remains in many institutions in the field of engineering and metallurgy. He was exceptional in his readiness to welcome new ideas late in life, retaining to the end a lively and informed interest in the institutions to which he had given so much, where a generation now in sight of retirement remembers the kindly wisdom of his advice and the high standards of efficiency and service which he set them as their goal.

\section{Guy ParsLoe}

\section{Prof. William Moffitt}

ON December 19, 1958, William Moffitt, associate professor of chemistry in Harvard University, died suddenly of a heart attack at the age of thirty-three in Cambridge, Massachusetts. Thus ended a brilliant career which already had a great impact on his chosen field of theoretical chemistry and seemed destined to go on to even higher levels of achievement.

Moffitt was born on November 9, 1925, in Berlin. His father, a British citizen, was in Germany on a government mission. Moffitt's early schooling was by private tutoring, but at the age of eleven he became 